\title{
FRESH FRUIT BUNCH QUALITY EFFECTS FOR OIL LOSS AND CRUDE PALM OIL PRODUCTION WITH SEM PLS ANALYSIS METHOD
}

\author{
SYUFRIANTO $^{1}$, ERRY RIMAWAN ${ }^{2}$, GUSNI SUSHANTI $^{3}$ \& FARIDA ELMI ${ }^{4}$ \\ ${ }^{1,2,3}$ Department of Industrial Engineering, Mercu Buana University, Jakarta State, Indonesia \\ ${ }^{4}$ Department of Magister Management, Mercu Buana University, Jakarta State, Indonesia
}

\begin{abstract}
CPO productivity is very important for palm oil entrepreneurs, it has been the benchmark in assessing the performance of oil palm plants. If there is a CPO withdrawal that is not being met by the target, this will result in a loss. One of the factors contributing to the low production of CPO is the amount of oil loss and poor quality of the oil palm bunches. The problem is that not all types of quality affect oil losses and CPO production. The analysis used is SEM PLS intelligent PLS software. The analysis results showed that low CPO production was unripe, abnormal fruit, lost oil loss on station and oil loss in final effluent. The results of the CPO production problem analysis using the SEM PLS analysis method with smartPLS version 3.2.8 showed that the quality of FFB was significantly affected (0.705) in the event of oil loss in the unripe and fruit indicators. while oil losses significantly affected (0.980) CPO production

KEYWORDS:FFB Quality, Oil Losses, CPO \& SEM-PLS
\end{abstract}

Received: Dec 23, 2019; Accepted: Jan 13, 2020; Published: Jul 18, 2020; Paper Id.: IJMPERDJUN2020382

\section{INTRODUCTION}

The development of the palm oil industry in Indonesia shows a positive trend based on data from the Indonesian Plantation Statistics Book (Perkebunan, 2017), palm oil development in Indonesia between 1980 and 2018 is likely to increase. Likewise, palm oil production (CPO) continued to increase yearly on average $11.50 \%$ every year.

However, Indonesia's average national OER level is only 22-23\%, although many individual factories have achieved over 23\% Oil Production (OER). Palm oil producers have been challenging to improve oil extraction (OER) levels as it is a management tool in assessing plant and plantation performance. The major factors affecting the OER are high yields of fresh fruit bunches and efficient processing of crops. Production costs, yield per hectare and OER are three key factors in assessing the performance of palm oil producers. And in assessing the performance of the oil palm plant which is the standard reference is the achievement of OER (Turner and Gillbanks, 2003).

The duration of formation has the effect on fresh fruit bunch (FFB) being nearly cooked or damaged (defective) resulting in loss of free fatty acid levels and lowering FFB weight. More specifically, this study aims to analyze whether the quality of fresh fruit bunches delivered to the factory affects oil production productivity (OER)

\section{STUDY LITERATURE}

The results of the bunches analysis show different oil levels between cooked and crude fruits (Mohanaraj, $\mathrm{S} \&$ Donough, C, 2016). According to Zulkefli, et al (2017) field study that sends immature and over-cooked fruit to factories contributing significantly to the degradation of CPO plant production, causing oil loss at several stages of 
the process and causing low OER.). Handayani. M and Hamidi.W (2015) mentioned that there are several factors affecting the production of palm oil industry, namely capital, raw materials and labor. Rimawan, et al, (2018) in their study found that quality levels have a significant effect on reducing losses.

One analytical method that can be used to detect fruit quality effects with oil loss is PLS structural equation model (Wong, 2013). According to Sarstedt et al (2017) to estimate latent variable relationships, the PLS method can be used. There are two submodels in the PLS structural equation model namely the internal model and the external model (Wong, 2013). The advantage of this model is that the sample size does not need to be large. Partial Least Square can be used to validate the theory as well as to explain whether there is a relationship between latent variables or not.

\section{METHODOLOGY}

This study uses SEM-PLS statistical analysis to analyze the impact of FFB on oil loss and CPO production. This method processes data from three variables, such as variable data processing tables, analyzed using smartPLS3 software.

Table 1: Variable Laten

\begin{tabular}{|l|l|l|}
\hline \multicolumn{1}{|c|}{ Variable } & \multicolumn{1}{|c|}{ Code } & \multicolumn{1}{c|}{ Indicator } \\
\hline FFB Quality & K1 & Unripe \\
\hline & K2 & Ripe \\
\hline & K3 & Over-Ripe \\
\hline & K4 & Brondolan \\
\hline & K5 & Empty Bunch \\
\hline & K6 & Long Stalk \\
\hline & K7 & Abnormal Fruit \\
\hline Oil Losses & L1 & Empty Bunch \\
\hline & L2 & Press Fibre \\
\hline & L3 & Solid Decanter \\
\hline & L4 & Final Effluent \\
\hline CPO & P1 & OER \\
\hline & P2 & Oil Losses On FFB \\
\hline
\end{tabular}

The hypothesis of this study is to see the effect of FFB quality on oil losses and CPO production. In this case, the investigation hypothesis is as follows:

- H1: FFB quality variables have an impact on the amount of oil losses.

- H2: FFB quality variables have an impact on $\mathrm{CPO}$ production

- 3 H3: Oil Loss Variables have an impact on CPO production 


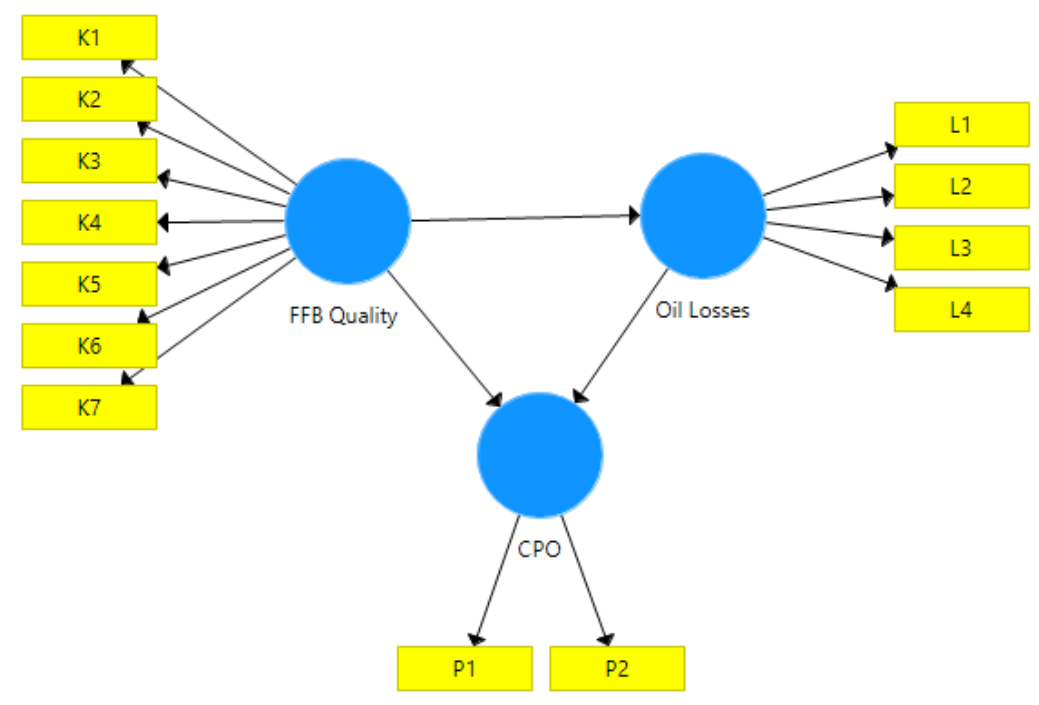

Figure 1: SEM PLS Research Model

\section{RESULTS}

\section{Evaluation of SEM PLS Method}

This study uses a reflective model, so that the assessment level follows the standard reflective model of reflective external validation \& internal model validation (Sarstedt et al., 2017). Measurement models are evaluated using reliability and validity. For reliability, you can use Cronbach's Alpha. This value reflects the reliability of all indicators in the model. The minimum value is 0.5 , and can also use the $\rho c$ (composite reliability) value interpreted as the Alpha Cronbach's value.

\section{Evaluation of Measurement Model (Outer Model)}

\section{Internal Consistency Reliability}

Table 1: Composite Reliability

\begin{tabular}{|l|c|}
\hline \multicolumn{1}{|c|}{ Variable } & CR \\
\hline CPO & 1.000 \\
\hline FFB Quality & 0,762 \\
\hline Oil Losses & 0,677 \\
\hline
\end{tabular}

\section{Indicator Reliability}

Table 2: Indicator Reliability

\begin{tabular}{|l|c|c|}
\hline \multicolumn{1}{|c|}{ VaribelLaten } & Kode & Outer Loading \\
\hline FFB Quality & K1 & 0,736 \\
\hline & K7 & 0,831 \\
\hline Oil Losses & L1 & 0,608 \\
\hline
\end{tabular}




\begin{tabular}{|l|l|l|}
\hline & L4 & 0,815 \\
\hline $\mathrm{CPO}$ & $\mathrm{P} 1$ & 1,000 \\
\hline
\end{tabular}

\section{Convergent Validity}

Table 3: Average Varian Extracted

\begin{tabular}{|l|c|}
\hline \multicolumn{1}{|c|}{ Variabel } & AVE \\
\hline Cpo & 1.000 \\
\hline FFB QUALITY & 0,616 \\
\hline Oil Losses & 0,517 \\
\hline
\end{tabular}

Discriminant Validity

Table 4: Fornell-Larcker Criterion

\begin{tabular}{|l|c|c|c|}
\hline \multicolumn{1}{|c|}{ Variable Laten } & CPO & $\begin{array}{c}\text { FFB } \\
\text { Quality }\end{array}$ & Oil Losses \\
\hline CPO & 1,000 & & \\
\hline FFB Quality & 0,705 & 0,785 & \\
\hline Oil Losses & 0,991 & 0,705 & 0,719 \\
\hline
\end{tabular}

Evaluation of structural measurement (Inner model)

Collinierity Assessment

Table 5: Vif Inner Model

\begin{tabular}{|l|c|c|c|}
\hline \multicolumn{1}{|c|}{ Variable Laten } & CPO & $\begin{array}{c}\text { FFB } \\
\text { Quality }\end{array}$ & Oil Losses \\
\hline CPO & & & \\
\hline FFB Quality & 1,987 & & \\
\hline Oil Losses & 1,987 & & 1,000 \\
\hline
\end{tabular}

\section{Structural Model Path Coefficient}

Table 6: Coefficient and Effect Evaluation of Structural Model

\begin{tabular}{|l|c|c|c|}
\hline \multicolumn{1}{|c|}{ Effect } & Co & T Statistic & P Value \\
\hline CPO -> CPO & 0,040 & 0,356 & 0,722 \\
\hline FFB Quality -> Oil Losses & 0,093 & 7,573 & 0,000 \\
\hline Oil Losses -> CPO & 0,028 & 35,618 & 0,000 \\
\hline
\end{tabular}




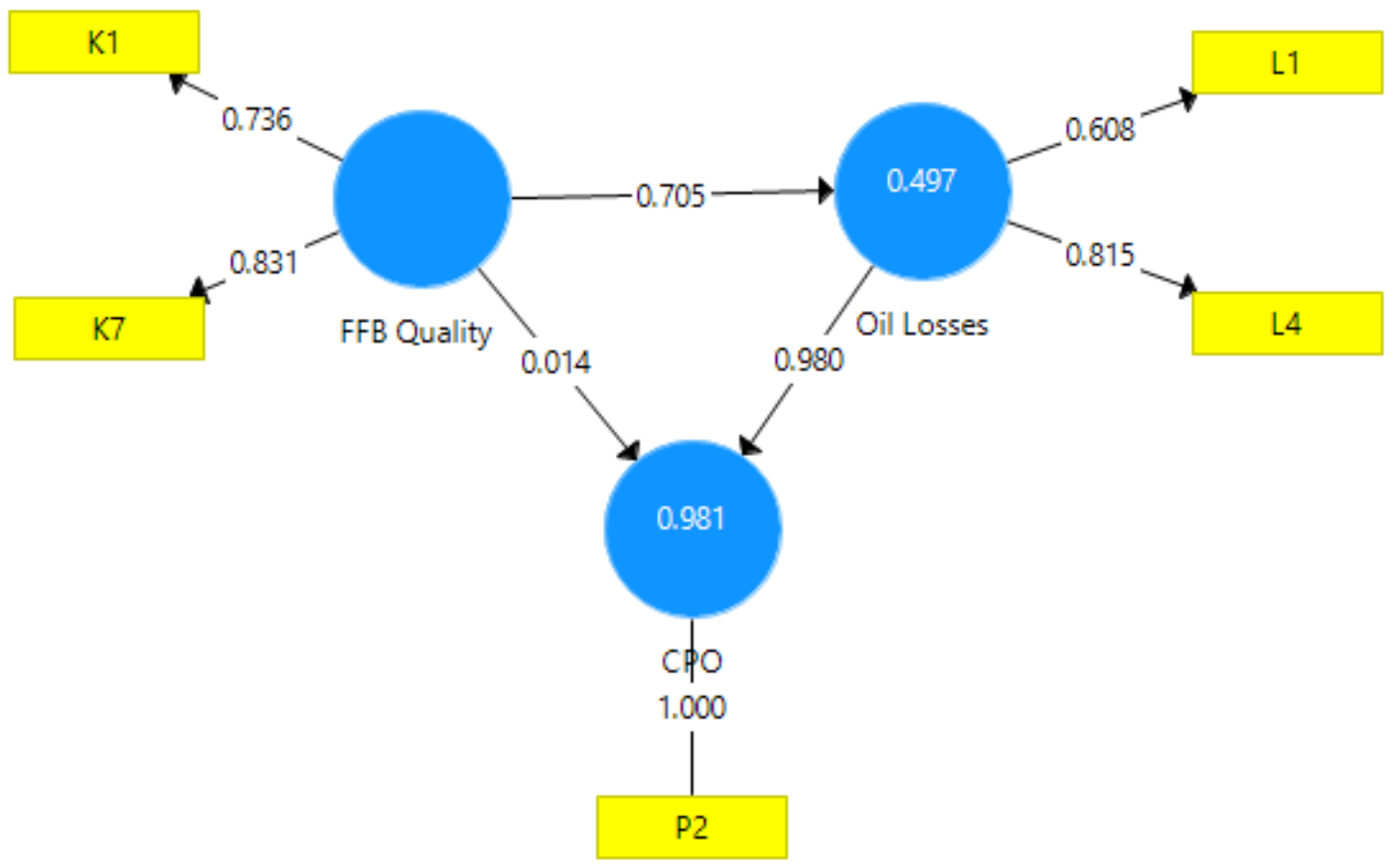

Figure 2: Result of Structural Model

\section{Coefficient Determination}

Table 7: Determination Coefficient

\begin{tabular}{|l|c|}
\hline Variabel Manifest & R-Square \\
\hline CPO & 0.981 \\
\hline Oil Losses & 0.500 \\
\hline
\end{tabular}

\section{Effect Size}

Table 8: Effect Size

\begin{tabular}{|l|c|c|c|}
\hline Variabel Manifest & CPO & FFB Quality & Oil Losses \\
\hline CPO & & & \\
\hline FFB Quality & 0,705 & & 0,705 \\
\hline Oil Losses & 0,980 & & \\
\hline
\end{tabular}

\section{CONCLUSIONS}

The results of the CPO production problem analysis using SEM PLS analysis method with smartPLS software version 3.2.8 showed that the quality of FFB significantly affected (0.705) on the occurrence of oil loss in the crude and fruit indicators. while oil losses significantly affected (0.980) CPO production.

Recommendations for further research are to look at factors that cause high oil losses at workplaces, particularly the final effluent and empty bunches. 


\section{REFERENCES}

1. Farahida Zulkefli, Nasuddin Othman, Syahrizan Syahlan, Mohd Rasdi Zaini, M. A. B. (2017). Fresh Fruit Bunch Quality and Oil Losses in Milling Processes as Factors That Affect The Extraxtion Rate of Palm Oil. International Journal of Agriculture, Forestry and Plantation, 5, 99-103.

2. Meri Handayani, Wahyu Hamidi, D. S. (2015). Analisis Faktor-faktor Produksi yang Mempengaruhi Industri Crude Palm Oil (CPO) Di Kabutapen Rokan Hlir (STUDI KASUS PT. SAWIT RIAU MAKMUR). Jom FEKON, 2(2).

3. NAGAPPAN, M., and T. RAVICHANDRAN."PERFORMANCE AND EMISSION CHARACTERISTICS OF PALM OIL AS AN ALTERNATE FUEL IN DIESEL ENGINE."International Journal of Mechanical and Production Engineering Research and Development (IJMPERD) 7. 6, Dec 2017, 417-424

4. Mohanaraj, S, N., \& Donough, $C, R$. (2016). Harvesting practices for maximum yield in oil palm: results from a re-assessment at IJM plantations, Sabah. Oil Palm Bulletin 72, 72(May), $i$.

5. Perkebunan, D. J. (2017). STATISTIK PERKEBUNAN INDONESIA 2016 -2018 (E. M. Widya Khonik Zuraina, Eko Pudjianto, Asep Udin, Susilo Novianto Damarjati, ed.). Jakarta: SekretariatDirektoratJenderal Perkebunan.

6. Hymavathi, D., G. Prabhakar, and B. B. Sarath. "Biodiesel production from vegetable oils: an optimization process." Int J Chem Petrochem Technol, 4 (2), 2130 (2014).

7. Rimawan, E., Mardono, U., \& Purba, H. (2018). Mathematical Modeling with Sem - PLS in Elimination of Six Big Losses to Reduce Production Cost of Steel Factories. 3(10), 404-409.

8. Rao, B. Subba, et al. "Studies on exhaust emissions and combustion characteristics of tobacco seed oil in crude form and biodiesel from a high grade low heat rejection diesel engine." International Journal of Industrial Engineering and Technology 3.1 (2013): 27-36.

9. Sarstedt, M., Ringle, C. M., Smith, D., Reams, R., \& Hair, J. F. (2014). Partial least squares structural equation modeling ( PLS-SEM ): A useful tool for family business researchers. Journal of Family Business Strategy, 5(1), 105-115.

10. Rao, N. Venkateswara, MVS Murali Krishna, and P. V. K. Murthy. "Comparative studies on exhaust emissions and combustion characteristics of tobacco seed oil in crude form and biodiesel form in direct injection diesel engine." International Journal of Mechanical and Production Engineering Research and Development (IJMPERD) 3.4 (2013): 129-142.

11. Wong, K. K. (2013). Partial Least Squares Structural Equation Modeling ( PLS-SEM) Techniques Using SmartPLS. Marketing Bulletin, 2013, 24, Technical Note 1. 